\title{
INTERNATIONALIZATION OF STOCK EXCHANGES AND OF FINANCE. WORKING OF THE GOLD STANDARD AND THE EUROPEAN SINGLE CURRENCY
}

\author{
INTERNACIONALIZACIÓN DE LAS BOLSAS Y DE LAS \\ FINANZAS. FUNCIONAMIENTO DEL PATRÓN ORO Y LA \\ MONEDA ÚNICA EUROPEA
}

\section{(ARTÍCULO BILINGÜE)}

Carlos Díaz Gómez (Traducción de Antonio Torrero Mañas): Universidad de Alcalá de Henares. Madrid (España)

carlos_diazgomez@yahoo.com

\section{CURRÍCULUM VITAE DE CADA AUTOR}

Doctor en Filosofía por la Universidad Complutense de Madrid (España) con Premio Extraordinario, Licenciado en Derecho por la Universidad Complutense de Madrid (España) con Premio Extraordinario, Licenciado en Altos Estudios Constitucionales con Premio Extraordinario y Profesor de la Universidad Complutense de Madrid (España). Autor de numerosos libros y artículos en revistas especializadas y universitarias.

\section{ABSTRACT}

Within the broad field generated by the relationship between finance and economics, two issues attracted particular attention. The financial crises of international and growing role in worldwide stock markets and institutions related to stock markets, 
focus our attention in this article. We describe the basic features of the international financial system, among which financial instability and volatility of markets. In shaping our economic knowledge is very important to the thinking of Keynes. The 1987 crash on Wall Street was transmitted to all world markets, prompting widespread public intervention to support the liquidity and solvency of the institutions. The country that suffered least the crash was Japan, whose stock seemed immunized although PER levels tripling to that in the other markets.

\section{KEY WORDS}

Economy - Financial System - Depression - Stock market - Keynes

\section{RESUMEN}

Dentro del amplio campo que generan las relaciones entre finanzas y economía, dos temas atraen especialmente la atención. Las crisis financieras de carácter internacional y el protagonismo creciente en todo el mundo de las bolsas y de las instituciones relacionadas con los mercados bursátiles, centrarán nuestra atención en este artículo. Se exponen las características fundamentales del sistema financiero internacional, entre las cuales destacan la inestabilidad financiera y la volatilidad de los mercados. En la conformación de nuestro saber económico es muy importante el pensamiento de Keynes. La crisis de 1987 en Wall Street se transmitió a todos los mercados del mundo, obligando a una intervención pública generalizada para respaldar la liquidez y la solvencia de las instituciones. El país que menos sufrió el desplome fue Japón, cuya bolsa parecía inmunizada pese a que los niveles de PER triplicaban al existente en el resto de los mercados.

\section{PALABRAS CLAVE}


Economía - Sistema Financiero - Crisis - Mercado bursátil - Keynes

\section{ÍNDICE}

\section{Presentation}

2. Keynes's financial concerns

3. Central features of the international financial system

3.1. Financial instability and market volatility

4. Notes

5. Bibliography

\section{TEXTO:}

\section{Acknowledgements}

I wish to thank the employees at the Library of the Faculty of Economics and Business Administration of the University of Alcala for the efficiency and attention with which they have taken care of my continual demands for bibliographic material.

\section{Presentation}

This book which I offer to the reader is made up of four works undertaken during the last few years. These works are linked by the fact that they all deal with events of major concern about the relationships between finance and economics.

Within so broad a realm, two questions have drawn my attention: international financial crises and the growing protagonism all over the world of stock exchanges 
and of those institutions related to the stock exchange markets. These two questions are interrelated, and it is precisely the consideration of these relationships which has inspired me the conception of the works which I now present.

The financial crisis phenomenon is extraordinarily wide and complex. And in two concrete instances stock markets (NOTE1) appear as an element which contributes to its comprehension. First, recent financial crises have all taken place very quickly. However, and contrary to the debtor countries crises which started in 1982, introducing the so-called 'lost decade', recoveries have neither taken much time. And second, there are very serious concerns about the possibility that we are immersed in a financial bubble, about the possibility that we are undergoing excessive overvaluation of stock markets, together with a cumulative process which might tend to amplify it, leading us to a more and more vulnerable position.

As to stock exchanges and the institutions related to them, the inception of new stock markets and the spectacular increment in the volume of market capitalisation as well as of dealings walk together with the growing internationalization of professionally managed portfolios. This means, firstly, that the assets quoted on organized markets, which are subject to automatic liquidation, are more and more important in the international capital flows pattern; and, secondly, that it is essential to consider the criteria and parameters investors use. In so doing, the connection between macroeconomics and professional portfolio management, which includes financial analysis techniques, grows in importance.

\section{Keynes's financial concerns}

In the making up of our economic knowledge Keynes's ideas are of sterling importance. In fact, one part of the economic science, as far as macroeconomics is 
concerned, is guided by his proposals, whereas the other one adopts their rejection as its analytical reference.

This essay does not intend to analyse the currency of the stabilizing proposals based upon Keynes's contribution, nor the reasons why they have been overcome. I will try to explore other streaks in the work of this great English economist which may do as bedrock to think about present financial problems in the world.

In order to limit my subject matter, those which have been considered Keynesian stabilizing proposals are summarily set out. So brief an indication will do for an introduction to focus this chapter's subject.

Most have considered the fundamental Keynes's contribution to be a set of proposals that have made up the basis for the management of the economy through slight correcting touches (fine tuning) in a scenario featuring two central elements: 1) On the inner front, growing presence of the State in the economy; and 2) internationally, a certain institutional arrangement which provided a stable framework together with a set of rules for correcting external account disequilibria.

State intervention, preferably fiscally, in the interior, and the maintenance of fixed but adjustable exchange rates abroad were the main instruments which made possible to keep economies' course at a satisfactory growing rate within a stable framework.

This pattern worked out during the three decades following World War II, but it broke down in the 1970s. On the inner front, because of lack of flexibility in the economies to adapt to the changes demanded by the new relative prices imposed by the energy crisis. Internationally, distrust of the ability of the United States economy 
to control liquidity and inflation triggered the breakdown of the international financial order established at Bretton Woods, and exchange rate flexibility imposed.

The phenomenon known as stagflation (inflation and stagnation) came to certify economies' inability to adjust, and it meant the triumph of monetarism, whose proposals, advanced in earlier decades, found at that time, second half of the seventies, the adequate conditions to impose. Fight against inflation, distrust of any compensating state intervention, and exaltation of private initiative, as well as of markets, make up the central features of the new creed, which has guided ever since the internal economic management of the economies and the working of the international financial system.

Keynes's work has had to bear almost anything, including the pretension to integrate it with Marxism, which he disqualified with a rich arsenal of invective; but, most probably, the greatest mystification ever has been to take it for a memorandum book, a compendium of rules, a vademecum of ready-to-use recipes. If there is a clear line Keynes never abandoned, it is the consideration of economics as a method for tackling economic problems which should always be considered in their own background, taking into account, in a special way, the opinion environment and those convictions and conventions present in society.

Out of the many existing interpretations of the essentials of Keynes's work, the one which has imposed ought not to be taken for the best one. It considers him as an essentially monetarist economist who, nevertheless, prescribed fiscal activism, distrustful of monetary policy capacity as well as of market forces.

There is another interpretation, supported by Meltzer, which brings together with greater fidelity the English economist's key ideas, as to the principles which must guide economic policy. According to this interpretation, Keynes, far from being an 
advocate for some policy based upon frequent handling of the instruments -mainly interest rates- in the short run, did support a stable economic framework for the long run, in order to avoid, precisely, the need for continuous encouraging or compensating interventions.(NOTE2)

According to Meltzer, the key point for Keynes was to keep up investment at an adequate level and dampen its fluctuations. Rather than trust or distrust monetary policy to regulate the cycle, Keynes intends to prevent important fluctuations by setting up an encouraging investment framework for the long run. Keynes shows evident distrustful signs for the appropriateness and effectiveness of monetary and fiscal measures to correct, in the short run, the course of events.

Investment is the central variable for Keynes. And its evolution has cyclical components. But the main reason which may give way to a collapse of investment is the sharp change which may eventually take place in the marginal efficiency of capital, because of excess of speculation in the stock exchange. The key question for investment to be kept up at the right levels, and for the adopted measures to have the intended effects, concerning both wages and interest rates, involves an as reduced as possible risk level. The attainment of this objective requires a stable expectations atmosphere, in order to minimize the risk due to variability and uncertainty.

Uncertainty is the enemy to overcome. The enemy to defeat must be «the dark forces of time and ignorance which envelope our future» (1936, VII, p. 155). Everything seems to indicate, however, that volatility, risk, and uncertainty dominate at present the international finance scene. If this is so, it will probably be worth the while to look into Keynes's work in search for inspiration to tackle our present economic problems. But in no way to find among the proposals advanced by him to face the questions of his time any recipe for us today. 
As far as international matters are concerned, Keynes left, partially set out in practice, his ideas about the institutional arrangement set up after the war. We know what he wanted and the reasons which supported his proposals. And these stemmed to a great extent, as The General Theory did, from the experience of the Great Depression.

The Great Depression was the decisive event in his career as an economist. It prompted his analytical talent towards the most suitable terrain for him. The central question that kept him busy during the twenties was finding out the reasons for the United Kingdom economic atony at a time when the world economy was expanding. From 1929 on, his goal would progressively be trying to disentangle the mechanisms of a mysterious and complex phenomenon, with financial roots, its epicentre located in the United States, and worldwide-reaching effects. This phenomenon involved some disarrangement in the delicate finance machinery, or as he would expressively declare: «But today we have involved ourselves in a colossal muddle, having blundered in the control of a delicate machinery, the working of which we do not understand» (1930, IX, p. 126).

One of the main reasons which, according to Keynes, caused the Great Depression was the break-up of the world financing flows, due to lesser primacy of his country as an international banker, a fact associated with the reduction in the surpluses in the British balance of payments. Other countries, in particular the United States, were reluctant to take up their part as an international banker in a stable and permanent fashion. Financial resources 'artificial' demand on central banks' behalf to back up their currencies under the gold standard regime, together with the drainage of financial resources towards the Wall Street speculative turmoil, contributed to the collapse of the international financial flows.

The arrangement of the international financing flows, suspicion towards market ability to carry out that function, and his wish to preserve certain autonomy in order 
to make national policies possible make up the fundamental points in Keynes's outlook (McKinnon, 1993, pp. 13-14).

As regards the international sphere, we can say that Keynes got to see his ideas shaped into reality at least to some extent. However, he did not advocate a clear line concerning the institutional reforms that he considered necessary to reduce the speculative strain in the markets. He did make clear, however, that some reduction in that tension would allow to minimize risk level, making in this way for the stability of the most volatile variable of all, i.e. investment. Nevertheless, it is important to note his impotence to propose remedies in the aforesaid direction, notwithstanding his being an economist with well-earned prestige regarding both fertility to advance solutions and originality in his points.

In The General Theory, in chapter 12 -«The state of long-term expectation»-, Keynes endeavours to reduce to essentials the difficult question of what our grounds to forecast the future is. To answer this question, he makes use of that part of the real world he knows best: the working of organized markets, which he follows with the care and dedication of an active participant.

As to this chapter 12, we are interested in his thoughts relating two questions: 1) the negative effects which may derive from speculation excess in markets whose working is based upon «the liquidity fetish», which does not exist for the society as a whole and which is clearly destabilizing, and 2) official quotations' deviations from intrinsic values, insofar as agents are not interested in considering firms' fundamental data to make their decisions. Instead, they will try to guess the other market participants' reactions.

Chapter 12 is the least general in the book, since its reflections' background is limited to the Anglo-Saxon world. It could even more precisely be said that it is limited to 
that of the US. Its reading somehow causes frustration, because after having denounced the instability which derives from investment being the result of the activities carried out in a casino, Keynes does not formulate any straightforward proposals to reduce such speculative tension, beyond the suggestion to make transactions more expensive, an idea Tobin would afterwards collect. The main conclusion he comes to consists in advocating encouragement of public investment decisions, isolating them from the «disobedient markets psychology». He left to us, it is true, a brilliant and subtle description; evidence of his stock exchange virtuosity, and above all, thoughts which may inspire our own analysis today. And this is, in my opinion, and bearing in mind that we are talking about such a delicate question, a legacy of no little importance.

Thus the ideas which preside today's world financial arrangement are the opposite to those supported by Keynes in his pursuit of the minimum possible instability and uncertainty levels, namely, as reduced as possible risk level which would encourage positive and sharp-change-free evolution of investment. In the international order, the International Monetary Fund (IMF), deprived of its basic function (NOTE3), seeks its institutional justification acting as an urgency resort to stifle the disequilibria provoked by extremely fluid and nervous capital mobility, susceptible of creating cumulative excesses and spasmodic withdrawals. Every country, on the other hand, must take into account as an essential variable the international financial markets' reactions, which punish expeditiously the adopted decisions, wiping out in practice any possibility to adopt, as Keynes intended, any measures with a certain degree of autonomy.

\section{Central features of the international financial system}

In the mid seventies, a new stage in the financial order begins, both nationally and internationally. 
On the inner front, interest rate strong increases, as a consequence of the shift occurred in monetary policy, which started to concentrate on the quantity of money to bring inflation under control, forced financial systems' liberalization and deregulation, in order to encourage competition and to increase institutions' capacity to adapt to changing situations. This is how the breakdown of the regulatory structure created by the Great Depression took place. The former promoted a very restrictive framework, with little room for competition and for market forces free operation. It was, in compensation, very stable, due to fat margins, companies' financial soundness, and public debt weight in banks' balance sheets.

In the United States, the first two postwar decades were of absolute financial stability; Minsky (1977) (NOTE4) refers to that period as abnormal, because what is normal, according to this economist, is that market forces, operating in finance, give rise to systemic instability. Thus from 1966 on normality begins to be regained, with instability episodes which have not ceased ever since.

As to international financing, exchange rate flexibility, financial resources general mobility, and the shift occurred in dominant ideas on economics handed over the main part to private financial institutions. Allocation of funds from oil-exporting countries to importing ones with external account deficits shows clearly how the international private banks had assumed the starring role, leaving to the IMF a secondary part.

The traumatic ending of that experience also proclaims what the ensuing working pattern would be like. Indeed, since 1982, after debtor countries had acknowledged their impossibility to serve the debt, the Federal Reserve direct involvement to solve the problem created by the harmed US banks' assets took place. At the same time, 
there is a turning to the IMF for this institution to implement precise adjustment policies which debtor countries must follow.

According to the preceding ideas, it seems justified to state that the essential features of the international financial framework are: a) financial systems' instability and market volatility, and b) private institutions' primacy in the international financing.

\subsection{Financial instability and market volatility}

Episodes of national banking systems crises have abounded during the last two decades, as a result of tougher competition and of difficulties for entities to adapt to a more deregulated framework. Time dimension, always key in economics, is of special importance when it comes to the financial sector. Indeed, the latter is likely to incubate problems for a long time, their true dimension being in this way concealed. Furthermore, it takes time for the consequences of the adopted decisions to fully show up. As a result, the magnitude of the difficulties is always surprising when they finally arise.

This chapter undertakes to consider the standing of Keynes's financial concerns. It should be noted, however, that amongst this English economist's many contributions, there are not any considerations concerning banking crises, nor any proposals regarding national banking systems institutional arrangement (NOTE5). We will thus concentrate on foreign exchange and stock exchange markets.

Thurow (1996, pp., 223-224) reminds us of the fact that at the beginning of the seventies almost every economist considered that flexible exchange rates would contribute to economic and financial stability. Reality, however, has not matched these expectations. Currency prices in foreign exchange markets have fluctuated widely, with respect to one another as well as with regard to the anchors which would supposedly rule prices' evolution. In particular, exchange rates have shown 
strong deviations from expected prices according to the purchasing power parity theory (Rogoff, 1996).

These deviations of currency prices from what we may regard as 'intrinsic value' or 'fundamentals' are generally considered to be the result of financial markets' distortional effects. The reason for these is to be found in the fact that professional investors' goal is not to operate paying close attention to the differences they observe between intrinsic values (whatever the method employed for their assessment) and market ones, placing their bets on their convergence in the long run. Far from this, their strategy is based upon estimation of the other participants' reactions.

This is Keynes's view, and no one may be surprised to find the following paragraph often quoted by today's market behaviour researchers:

«Professional investment may be likened to those newspaper competitions in which the competitors have to pick out the six prettiest faces from a hundred photographs, the prize being awarded to the competitor whose choice most nearly corresponds to the average preferences of the competitors as a whole; so that each competitor has to pick, not those faces which he himself finds prettiest, but those which he thinks likeliest to catch the fancy of the other competitors, all of whom are looking at the problem from the same point of view. It is not a case of choosing those which, to the best of one's judgement, are really the prettiest, nor even those which average opinion genuinely thinks the prettiest. We have reached the third degree where we devote our intelligences to anticipating what average opinion expects the average opinion to be. And there are some, I believe, who practise the fourth, fifth and higher degrees»

(1936, VII, p. 156). 
In two important works (McKinnon, 1996; McKinnon and Ohno, 1997) about the relationship between the American dollar and the yen exchange rates, one hypothesis is set forth to explain the extraordinarily great differences observed between the prices of those two currencies. According to this hypothesis, the reason for those differences is not to be found in the fundamental data trend, but in the fact that managers make their decisions in response to continuous changes occurred in new information, particularly relating monetary policy directing lines and expectations and conventions generated in the markets.

As far as stock markets are concerned, the panorama has been dominated by wide fluctuations. The crash of October 1987 prompted economists to think about the reasons and consequences of stock market crises, with the Great Depression as a permanent backcloth. Research carried out at the request of the President of the United States concluded that, indeed, equity markets' volatility had increased, especially since the generalization of derivatives (Brady, II, pp. 5-6).

Wall Street 1987 crash reached markets all over the world, forcing a general public intervention to back up institutions' liquidity and solvency. Japan happened to be the country least affected by the crash. Its Stock Exchange seemed to be immunized, in spite of the fact that PER (NOTE6) levels there were threefold those ones existing in other markets.

A giant speculative bubble was getting bigger and bigger in Japan. A bubble filled up with equity and real estate markets, which resulted in a spectacular prices surge sustained by the banking system. The Japanese market slump which had begun at the turn of the eighties meant a terribly strict correction of stock and real estate prices, contributed to a deep banking crisis, and affected the growing rate of the Japanese economy, sinking it in a crisis in which it is settled ever since. 
In every instance, one of the financial crises' key elements is the crack of far too optimistic expectations, produced and sustained by the markets themselves. The sheer differences observed between market prices and those ones one would expect to derive from the fundamentals which legitimate an asset price and give that asset stability in the long run remind us of Keynes's ideas. It is a right time to go through the work of this great economist. The General Theory is a book inspired, it is important not to forget this, in the Great Depression which had the Wall Street crash as a threshold. In this book, Keynes distinguishes such activity as guessing market behaviour, which he names speculation, from that one which consists in valuing one particular asset's useful life profitability, for which he reserves the term enterprise.

Once the fact has been established that certain kinds of investments are ruled by the evolution of the stock market, Keynes takes the next step forward: profitability expectations of stock market traders are different from those of professional entrepreneurs. And they are different because so are their valuation patterns and the periods they consider. According to Keynes, speculative behaviour outweighs entrepreneurs' valuations.

Keynes's key idea to explain stock market investors' behaviour lies with the convention founded upon the assumption that «the existing state of affairs will continue indefinitely, except in so far as we have specific reasons to expect a change» (1936, VII, p. 152). It is not a belief firmly grounded upon reality, for experiences of frustrated expectations we have gone through in the past are conclusive. Nor does this idea of adopting a convention as the basis for our decision-making about future behaviour has any foundation on probability logic:

«We are assuming, in effect, that the existing market valuation, however arrived at, is uniquely correct in relation to our existing knowledge of the facts which will 
influence the yield of the investment, and that it will only change in proportion to changes in this knowledge»

(ibid., p. 152).

The existence of this convention in organized markets provides businesses with stability and continuity, and, so long as it keeps acting, investors may feel safe with the idea that the only risk they run consists of a change in the news to take place in the near future. They will try to make their own judgement about the probability attached to the occurrence of such an event. Within this frame of mind, any investment is considered to be safe in the short term. And, insofar as investors perceive that the aforesaid convention will not alter, or that they will otherwise be able to anticipate any eventual future changes, investments which are fixed for the community become liquid for the individual. The most important markets for investment -Keynes goes on- have been developed on the basis of this sort of reasoning, «but it is not surprising that a convention, in an absolute view of things so arbitrary, should have its weak points. It is its precariousness which creates no small part or our contemporary problem of securing sufficient investment» (ibid., p. 153).

The point referred to this convention which deserves to be highlighted in Keynes's approach is that, whenever agents are to make any of their decisions in an environment of uncertainty, they are psychologically prone to act imitating the other participants' reactions. When Keynes deals with participants' reactions in organized markets, he brings under examination some features which recall today's markets' recent evolution. Present-day markets do increase precariousness, and so their volatility, without the existence of any sound reasons which support the observed shifts in valuations. Among these features, the separation of ownership from management, a fact associated with the growing weight of shares in both individuals' and institutions' portfolios, matters a great deal. 
Ownership of listed shares throughout the public has become increasingly widespread. This enhances the effects of the separation of ownership from management, because «the element of real knowledge in the valuation of investments by those who own them or contemplate purchasing them has seriously declined». In such an environment of greater ignorance, ephemeral or trivial events may give rise to significant shifts in stocks' valuations; moreover, the conventional grounds for valuation «which is established as the outcome of the mass psychology of a large number of ignorant individuals is liable to change violently as the result of a sudden fluctuation of opinion due to factors which do not really make much difference to the prospective yield»; this means that «the market will be subject to waves of optimistic and pessimistic sentiment, which are unreasoning and yet in a sense legitimate where no solid basis exists for a reasonable calculation». (ibid., pp. 153-154).

A professional investor does not make up for the ignorant shareholder cognitive shortages, because that is not his job. An expert in not so much interested in estimating long-run yields as accurately as possible as in attempting to guess the shifts liable to occur in the public short-run conventional basis for valuation.

«They are concerned, not with what an investment is really worth to a man who buys it 'for keeps', but with what the market will value it at, under the influence of mass psychology, three months or a year hence. Moreover, this behaviour is not the outcome of a wrong-headed propensity. It is an inevitable result of an investment market organized along the lines described. For it is not sensible to pay 25 for an investment of which you believe the prospective yield to justify a value of 30, if you also believe that the market will value it at 20 three months hence»

$$
\text { (ibid., p. 155). }
$$


Thus, a professional investor concentrates his efforts on the analysis of all those news which experience suggests they affect investments' evolution. And this is the result of markets designed to catch hold of the so-called 'liquidity'.

«Of the maxims of orthodox finance none, surely, is more anti-social than the fetish of liquidity, the doctrine that it is a positive virtue on the part of investment institutions to concentrate their resources upon the holding of 'liquid' securities. It forgets that there is no such thing as liquidity of investment for the community as a whole» (ibid., 155).

Keynes denounces that in organized exchanges professionals and investment institutions do not devote themselves to defeating the secular enemies of society, that is, ignorance and uncertainty. Their most important goal is instead to be smarter and quicker than the rest and «to pass the bad, or depreciating, half-crown to the other fellow».

Of course, you can also find investors for the long run who work out investments' profitability and forget about both short-run fluctuations and the other participants' reactions. It is this other kind of investors who provide the market with a different look. But making accurate assessments about the future is far more difficult and takes much longer:

«It needs more intelligence to defeat the forces of time and our ignorance of the future than to beat the gun. Moreover, life is not long enough; -human nature desires quick results, there is a peculiar zest in making money quickly, and remoter gains are discounted by the average man at a very high rate»

(ibid., 157). 
The weight of speculation in the market is decisive to its instability conditions. This consideration of speculation as a disturbance factor, should it become the main element in the market, walked away from the traditional idea of speculation, as Kaldor (1939) timely analysed in an important article which went further and deeper into those questions pointed out by Keynes in chapter 12 of The General Theory. The traditional idea viewed speculation as a positive factor, to the extent that its practitioners provided the market with a superior degree of foresight. Otherwise, they would be eliminated. This improved knowledge guaranteed that their actions would contribute to a better resource allocation. Kaldor (1939, p. 102) classifies the effects of speculation according to its market importance. When it dominates the scene, those who make the best forecasts are certainly the ones to survive. But what then matters is the ability to anticipate other speculators' behaviour, over and above other real factors of a more permanent character. And although the less-fit may die out, the renewal of the population devoted to this activity ensures the continuity of the primacy of the activity inspired in the behaviour of the speculators as a whole.

The difference between entrepreneurs and speculators not only lies in their different goals, view of the firm and markets. Their knowledge is also different. And speculators, with their short-term perspective, demand for their activities a different training and education than entrepreneurs do. For all these reasons, if speculators get to impose their patterns of behaviour and assessment, if they become the dominant element in the economic life, their actions will distort business existence. In Keynes's view, as O'Donnell (1989, p. 258) has pointed out, both speculators and entrepreneurs must face an uncertain future. Entrepreneurs do nevertheless have some guidance to help them set their long-term goals in the right direction, provided they could make their decisions free of speculators' short-term criteria. As Keynes pointed out in 1938, in the last speech he delivered to the members of the National Mutual (NOTE7), speculative markets: 
«are governed by doubt rather than by conviction, by fear more than by forecast, by memories of last time and not by foreknowledge of next time. The level of stock exchange prices does not mean that investors know, it means that they do not know. Faced with the perplexities and uncertainties of the modern world, market values will fluctuate much more widely than will seem reasonable in the light of afterevents»

(1938, XII, p. 238).

\section{Notes}

1.- The terms stock market (USA) and stock exchange (UK) are used as synonyms throughout the text.

2.- Meltzer undertakes the defence of this interpretation in the following works: (1981): "Keynes's general theory: A different perspective", Journal of Economic Literature, vol. 19, March, pp. 34-64; (1983): "Interpreting Keynes", Journal of Economic Literature, vol. XXI, March, pp. 66-78; (1983): "On Keynes and monetarism", in D. Worswick and J. Trevithick (eds.): Keynes and the modern world. Proceedings of the Keynes centenary conference, Cambridge University Press; (1989): "Keynes on monetary reform and international order", in F. Capie and G. E. Wood (eds.): Monetary Economics in the 1980s. Hong-Kong, Macmillan Press; (1992): "Patinkin on Keynes and Meltzer", Journal of Monetary Economics, 29, pp. 151-162; (1996): "The general theory after sixty years", Journal of Post Keynesian Economics, Fall, vol. 19, $\mathrm{n}^{\mathrm{o}}$ 1, pp. 35-45. A careful review in Spanish of Meltzer's interpretation may be found in Torrero (1998, pp. 1027-1035).

3.- Ontiveros (1997) sets out in Spanish clearly and accurately the International Monetary Fund's evolution.

4.- Further references to Minsky's work may be found in Spanish in Torrero (1993). 
5.- These questions are dealt with in Spanish in Torrero (1998).

6.- Price earning ratio. Ratio of the market price of an ordinary share (UK) or common stock (USA) to the earnings per share or stock.

7.- Keynes was a Member of the Board of Directors of the National Mutual Life Assurance from September 1919 to October 1938. He was appointed Chairman in May 1921.

\section{Bibliography}

BRADY, N. F. (President) (1988): «Report of the presidential task force on market mechanisms», Washington, U. S. Government Printing Office.

McKINNON, R. I. (1996): «Dollar and yen», in M. Uzan (ed.), The Financial System under Stress. An Architecture for the New World Economy, Routledge, New York.

McKINNON, R. I., and OHNO, K. (1997): Dollar and yen. Resolving the economic conflict between the United States and Japan, The MIT Press.

KALDOR, N. (1939): «Speculation and economic stability», The Review of Economic Studies. Included in F. Targetti and A. P. Thirlwall (eds.), The Essential Kaldor, New York, 1989, Holmes \& Meier, where references are taken from.

KEYNES, J. M.: All references to Keynes are to the Collected Writings edited by The Royal Economic Society. In the bibliography the year of publication is indicated, the title of the book or article, as well as the corresponding volume and pages. In the quotations, the year of publication, the volume and the page. 
KEYNES, J. M. (1930):«The great slump of 1930», Essays in persuasion, vol. IX.

KEYNES, J. M. (1938): «Speech to the annual meeting of the national mutual, 20th February» (XII, pp. 231-239).

KEYNES, J. M. (1939): The general theory of employment, interest and money, vol. VII.

O'DONNELL, R. M. (1989): Keynes: Philosophy, Economics \& Politics, London, The MacMillan Press, Ltd.

ONTIVEROS, E. (1997): Sin orden ni concierto. Medio siglo de relaciones monetarias internacionales, Murcia.

ROGOFF, K. (1996): «The purchasing power parity puzzle», Journal of Economic Literature, vol. XXXIV, June, pp. 647-668.

THUROW, L. (1996): The future of capitalism. How today's economic forces will shape tomorrow's world, London: Nicholas Brealey Publishing.

TORRERO, A. (1993): La crisis del sistema bancario: Lecciones de la experiencia de Estados Unidos, Editorial Civitas, Madrid.

TORRERO, A. (1998): La obra de John Maynard Keynes y su visión del mundo financiero, Editorial Civitas, Madrid. 


\section{(Traducción)}

\section{Agradecimientos}

Deseo agradecer a los empleados de la Biblioteca de la Facultad de Ciencias Económicas y Empresariales de la Universidad de Alcalá la eficiencia y la atención con la que han atendido mis reiteradas demandas de material bibliográfico.

\section{Presentación}

El artículo que se ofrece al lector está integrado por cuatro trabajos realizados en los últimos años; tienen como nexo de unión abordar los acontecimientos de mayor interés respecto a las relaciones entre finanzas y economía.

Dentro de ese amplísimo campo dos temas han atraído, sobre todo, la atención: las crisis financieras de carácter internacional; y el protagonismo creciente en todo el mundo de las bolsas, y de las instituciones relacionadas con los mercados bursátiles. Estos dos asuntos están interrelacionados y es, precisamente, la consideración de estas relaciones lo que ha inspirado la concepción de los trabajos que se presentan.

El fenómeno de las crisis financieras es extraordinariamente amplio y complejo, y en dos puntos concretos aparece la bolsa como elemento que contribuye a su 
comprensión: 1) las crisis financieras recientes se han producido súbitamente, pero, contrastando con la crisis de los países deudores que se inicia en 1982 como pórtico de la llamada «década perdida», las recuperaciones se han producido también con gran rapidez, y 2) preocupa extraordinariamente la posibilidad de que estemos inmersos en una burbuja financiera, esto es, que exista una sobrevaloración excesiva de las bolsas, y un proceso acumulativo que tienda a amplificarla, alcanzándose una posición cada vez más vulnerable.

En cuanto a las bolsas e instituciones relacionadas con los mercados, la creación de nuevas bolsas y el incremento espectacular del volumen de capitalización y de contratación, van acompañados por la internacionalización creciente de las carteras de valores gestionadas con criterios profesionales. Esto implica, por una parte, que los activos cotizados en mercados organizados, susceptibles de liquidación inmediata, tienen cada vez más importancia en los flujos internacionales de capital; por otra, que es esencial tener en cuenta los criterios y parámetros utilizados por los inversores, con lo cual crece en importancia la conexión entre la macroeconomía y la gestión profesional de carteras, que incluye el empleo de las técnicas del análisis financiero.

\section{Las inquietudes financieras de Keynes}

La trascendencia del pensamiento de Keynes en la conformación de nuestro saber económico es muy importante. De hecho, una parte de la ciencia económica, en su vertiente macroeconómica, se orienta por sus propuestas, y otra toma como referencia analítica el rechazo de las mismas.

Esta reflexión no tiene por objeto analizar la vigencia de los planteamientos estabilizadores basados en la aportación de Keynes, o las razones por las que éstos han sido superados. Se intentará explorar otras vetas de la obra del gran economista 
inglés que pueden servir de base para reflexionar sobre la problemática financiera del mundo en la actualidad.

Para delimitar el campo objeto de análisis se exponen, de forma resumida, las que se han considerado propuestas estabilizadoras de Keynes o keynesianas. Esta brevísima alusión servirá de introducción para centrar el tema objeto de este capítulo.

Se ha considerado mayoritariamente como la aportación fundamental de Keynes que sus propuestas han fundamentado la conducción de las economías mediante leves toques correctores ("fine tuning") en un escenario con dos características esenciales: 1) presencia creciente del Estado en la economía en el frente interno, y 2) ordenamiento institucional en la esfera internacional que proporcionaba un marco estable, y unas reglas para la corrección de los desequilibrios en las cuentas exteriores.

La actuación del Estado, preferentemente por la vía fiscal, en el interior, y el mantenimiento de tipos de cambio fijos pero ajustables en el exterior, constituían los instrumentos principales que permitían mantener el rumbo de las economías con un crecimiento satisfactorio en un marco estable.

Este esquema funcionó en las tres décadas que siguieron a la Segunda Guerra Mundial, pero se derrumbó en la década de los setenta debido, en el frente interno, a la falta de flexibilidad de las economías para adaptarse a los cambios exigidos por los nuevos precios relativos impuestos por la crisis energética. En el orden internacional, la desconfianza en la capacidad de la economía norteamericana para controlar la liquidez y la inflación, provocó la ruptura del orden financiero internacional instaurado en Bretton Woods, imponiéndose la flexibilidad de los tipos de cambio.

El fenómeno de la estanflación (inflación y estancamiento) vino a certificar la incapacidad de las economías para ajustarse, y supuso el triunfo del monetarismo, 
cuyas propuestas, formuladas en décadas anteriores, encontraron entonces, en la segunda mitad de la década de los setenta, el clima adecuado para imponerse. La lucha contra la inflación, la desconfianza hacia cualquier actuación pública compensadora, y la exaltación de la iniciativa privada y de los mercados, integran los puntos fundamentales del nuevo credo, que ha orientado, desde entonces, la gestión interna de las economías y el funcionamiento del sistema financiero internacional.

La obra de Keynes ha tenido que soportar casi todo, hasta la pretensión de integrarla con el marxismo, al que el economista inglés descalificó con todo un rico arsenal de invectivas; pero, seguramente, la mayor mistificación haya sido considerarla como un prontuario, como un vademécum de recetas listas para su aplicación. Si hay una línea clara, de la cual Keynes no se desvió nunca, ésta fue considerar a la economía como un método de abordar los problemas económicos, los cuales habían de considerarse en su marco específico, teniendo en cuenta, de forma especial, el clima de opinión y las convicciones y convenciones que existieran en la sociedad.

De las muchas interpretaciones que existen acerca de lo esencial de la obra de Keynes, no debería considerarse como la más idónea la que se ha impuesto: la de un economista esencialmente monetario que, sin embargo, postuló el activismo fiscal, desconfiando de la capacidad de la política monetaria y de las fuerzas del mercado. Hay otra interpretación, defendida por Meltzer, que recoge con mayor fidelidad las ideas clave del economista inglés, en lo que se refiere a los principios sobre los que debe organizarse la política económica. Según esta interpretación, Keynes, lejos de ser partidario de una política basada en el manejo frecuente de los instrumentos principalmente el tipo de interés- en el corto plazo, lo que defendía era un marco económico estable en el largo plazo, que obviara, precisamente, la necesidad de actuaciones, incentivadoras o compensadoras con carácter continuo. (NOTA1) 
Según Meltzer, la cuestión clave para Keynes es mantener la inversión en un nivel adecuado y reducir sus fluctuaciones. Más que confiar, o desconfiar, de la política monetaria para regular el ciclo, lo que propone Keynes es prevenir las fluctuaciones importantes estableciendo un marco favorecedor de la inversión con un horizonte de largo plazo. Keynes muestra signos evidentes de desconfianza respecto a la conveniencia y efectividad de medidas monetarias y fiscales, en el corto plazo, para corregir el curso de los acontecimientos.

La inversión es la variable fundamental para Keynes, y su evolución tiene componentes cíclicos, pero la razón esencial que puede provocar un colapso de la inversión, es el cambio brusco susceptible de producirse en la eficiencia marginal del capital, como consecuencia de un exceso de especulación en la bolsa. La cuestión crucial para que la inversión se mantenga en niveles convenientes, y para que surtan efecto las medidas que se adopten, tanto en relación a salarios como a tipos de interés, es que el nivel de riesgo se mantenga lo más reducido posible. Este objetivo requiere un entorno de expectativas estables con objeto de minimizar el riesgo debido a la variabilidad y a la incertidumbre.

El enemigo a batir es la incertidumbre. El enemigo debe ser «derrotar las oscuras fuerzas del tiempo y la ignorancia que envuelven nuestro futuro» (1936, VII, p. 155). Todo parece indicar, sin embargo, que la volatilidad, el riesgo y la incertidumbre dominan ahora la escena de las finanzas internacionales. Si esto es así, seguramente será provechoso acercarse a la obra de Keynes en busca de inspiración para enfocar nuestros problemas actuales, pero de ninguna manera pretendiendo buscar alguna receta en las propuestas del economista inglés para abordar los problemas de su tiempo.

En el ámbito internacional, Keynes dejó, parcialmente plasmados en la práctica, sus planteamientos en la organización institucional instaurada en la posguerra. Sabemos 
lo que deseaba y las razones que impulsaban sus propuestas, y éstas derivaban, como la Teoría General, en buena medida de la experiencia de la Gran Depresión.

La Gran Depresión fue el acontecimiento decisivo en su carrera como economista, e impulsó su talento analítico hacia el terreno que le era más propicio. La cuestión fundamental que le ocupó en la década de los veinte, fue descubrir las razones de la atonía de la economía del Reino Unido en un mundo en expansión. A partir de 1929 su objetivo se centraría, de forma progresiva, en intentar desentrañar los mecanismos de un fenómeno misterioso y complejo, con el epicentro en los Estados Unidos, pero cuyos efectos alcanzaron a todo el mundo, y que tenía una raíz financiera. Se trataba de un desajuste en la delicada maquinaria de las finanzas, o como expresivamente declararía: «En la actualidad, nos hemos envuelto nosotros mismos en una colosal confusión, fallando en el control de un mecanismo delicado cuyo funcionamiento no comprendemos» (1930, IX, p. 126).

Una de las razones fundamentales que, a juicio de Keynes, provocaron la Gran Depresión, fue la interrupción de los flujos mundiales de financiación, debido al menor protagonismo de su país como banquero internacional, hecho asociado a la reducción de su excedente en la balanza de pagos. Otros países, en particular los Estados Unidos, se mostraban renuentes a tomar el relevo como banqueros internacionales, con carácter estable y continuo. La demanda «artificial» de recursos financieros por los bancos centrales para respaldar sus monedas en el régimen del patrón oro, y la absorción de recursos por el remolino especulativo de Wall Street coadyuvaron al colapso de las corrientes financieras internacionales.

El ordenamiento de los flujos de financiación internacional, la desconfianza en que esa función pudiera realizarla el mercado, y su deseo de preservar una cierta autonomía para que puedan llevarse a cabo políticas nacionales, constituyen los puntos fundamentales en la visión de Keynes (McKinnon, 1993, pp. 13-14). 
Pero si en la esfera internacional Keynes consiguió ver sus ideas expresadas en la realidad, al menos en parte, en el ámbito interno no formuló propuestas, ni preconizó una línea clara sobre las reformas de carácter institucional que entendiera necesarias para reducir la tensión especulativa en los mercados, aunque sí especificara que la disminución de esta tensión permitiría minimizar el nivel de riesgo, favoreciendo así la estabilidad de la variable más volátil, esto es, de la inversión. Es importante considerar, no obstante, la impotencia de proponer remedios en esa dirección, en un economista con prestigio bien ganado tanto de fertilidad en brindar soluciones, como de originalidad en sus planteamientos.

En la Teoría General, en el capítulo 12: «El estado de las expectativas a largo plazo», Keynes se plantea concretar la difícil cuestión de cuáles son los fundamentos sobre los que basamos nuestras previsiones de futuro, y para ello recurre a la parcela de la realidad que mejor conoce: al funcionamiento de los mercados organizados, los cuales sigue con la dedicación y el detalle de un partícipe activo.

Del capítulo citado interesan sus reflexiones sobre dos puntos: 1) los efectos negativos que pueden derivarse del exceso de especulación en mercados que funcionan sobre la base del «fetiche de la liquidez», la cual no existe para la sociedad en conjunto y es claramente desestabilizadora, y 2) las desviaciones de las cotizaciones de los mercados respecto al valor intrínseco, ya que los agentes no están interesados en decidir considerando los datos fundamentales de las empresas, sino que intentan adivinar las reacciones de los otros partícipes en el mercado.

El capítulo 12 es el menos general del libro, puesto que el ámbito de su reflexión se limita al mundo anglosajón, y aun puede decirse que a los Estados Unidos. También produce frustración, en cierto sentido, porque después de denunciar la inestabilidad que se deriva de que la inversión sea el resultado de las actividades de un casino, 
Keynes no formula propuestas claras para reducir la tensión especulativa, más allá de sugerir el encarecimiento de las transacciones, idea que más tarde recogería Tobin. Su principal conclusión es impulsar las decisiones públicas de inversión, aislándolas de la «desobediente psicología de los mercados». Nos dejó, eso sí, una descripción brillante y sutil, una prueba de su virtuosismo bursátil, pero, sobre todo, unas reflexiones que pueden inspirar nuestro propio análisis, lo cual, en mi opinión, tratándose de un tema tan delicado, parece un legado nada despreciable.

De manera que las ideas que presiden la organización financiera del mundo en la actualidad, son las contrarias a las defendidas por Keynes para procurar el menor nivel posible de inestabilidad e incertidumbre, esto es, el menor riesgo que favorezca una evolución positiva y sin variaciones bruscas de la inversión. En la organización internacional, el Fondo Monetario Internacional (FMI), privado de su función básica (NOTA2) busca su justificación institucional como recurso de urgencia para sofocar los desequilibrios provocados por una movilidad del capital extremadamente fluida y nerviosa, susceptible de generar excesos acumulativos y retiradas espasmódicas. Los países, por otra parte, han de considerar como variable esencial las reacciones de los mercados financieros internacionales, que sancionan de manera expeditiva las decisiones que se adopten, anulando en la práctica la posibilidad de adoptar medidas con un cierto grado de autonomía, como pretendía Keynes.

\section{Características fundamentales del sistema financiero internacional}

A mediados de la década de los setenta se abre una nueva etapa en la organización financiera, tanto en la vertiente nacional como internacional.

En el frente interno, las fuertes elevaciones de los tipos de interés, consecuencia del cambio operado en la política monetaria, que pasó a concentrarse en el control de la 
cantidad de dinero para dominar la inflación, forzó a la liberalización y desregulación de los sistemas financieros, para incentivar la competitividad y aumentar la capacidad de adaptación de las instituciones a situaciones cambiantes. Se inicia así la demolición de la estructura reguladora motivada por la Gran Depresión, que promovió un marco muy restrictivo, con poco espacio para la competencia y el juego de las fuerzas del mercado, pero que, como contrapartida, era muy estable debido a la amplitud de los márgenes, a la solidez financiera de las empresas y al peso de la deuda pública en los balances bancarios.

En los Estados Unidos, las dos primeras décadas de la posguerra fueron de absoluta estabilidad financiera; ese período lo califica Minsky (1977) (NOTA3) como anormal, puesto que lo normal, según este economista, es que las fuerzas del mercado, operando en finanzas, generen una inestabilidad sistémica; de manera que a partir de 1966 empieza a restaurarse la normalidad, con episodios de inestabilidad que no han dejado de producirse desde entonces.

En cuanto a la financiación internacional, la flexibilidad de los tipos de cambio, la movilidad generalizada de los recursos financieros y el cambio en las ideas dominantes en economía, traspasó el protagonismo a las instituciones financieras privadas. La asignación de los fondos procedentes de los países exportadores de petróleo hacia los importadores con déficit en sus cuentas exteriores, marca con nitidez que la banca privada internacional había asumido el protagonismo, relegando al FMI a un papel secundario.

El final traumático de esa experiencia anuncia también lo que sería el modelo de funcionamiento posterior. En efecto, a partir de 1982, con el reconocimiento por parte de los países deudores de su incapacidad para hacer frente al servicio de la deuda, se produce la implicación directa de la Reserva Federal con objeto de solucionar el problema de los dañados activos de la banca estadounidense; se recurre, al tiempo, al 
FMI para que esta institución instrumente las políticas de ajuste precisas que debían aplicar los países deudores.

A partir de lo anterior, parece justificado enunciar que las características esenciales del marco financiero internacional son: a) la inestabilidad de los sistemas financieros y la volatilidad de los mercados, y b) el predominio de las instituciones privadas en la financiación internacional.

\subsection{Inestabilidad financiera y volatilidad de los mercados}

Los episodios de crisis en los sistemas bancarios nacionales se han prodigado en las dos últimas décadas, como resultado del endurecimiento de la competencia y de la dificultad de adaptación de las entidades a un marco más desregulado. En el sector financiero tiene especial importancia la dimensión temporal, cuestión siempre fundamental en economía. En efecto, existe la posibilidad de incubar problemas largo tiempo, ocultando su auténtica dimensión; además, las consecuencias de las decisiones tardan en ponerse de relieve con toda su intensidad. El resultado es que cuando las dificultades afloran, siempre sorprende su importancia.

El objetivo de este capítulo es plantear la actualidad de las inquietudes financieras de Keynes, pero entre las muchas aportaciones del economista inglés no hay reflexiones sobre crisis bancarias, ni propuestas en relación a la organización institucional de los sistemas bancarios nacionales. (NOTA4) La atención se centrará, pues, en los mercados de divisas y en los bursátiles.

Thurow (1996, pp. 223-224) nos ha recordado que, al comienzo de los años setenta, casi todos los economistas confiaban en que los tipos de cambio flexibles contribuirían a la estabilidad de la economía y de las finanzas. La realidad no ha 
respondido, sin embargo, a estas esperanzas; la evolución de las cotizaciones de las divisas en los mercados de cambio ha tenido fuertes fluctuaciones, tanto entre ellas como en relación a los anclajes que se suponía que gobernarían la tendencia de las cotizaciones. En particular, los tipos de cambio han mostrado importantes diferencias con las cotizaciones que hubieran correspondido según la teoría de la paridad del poder de compra (Rogoff, 1996).

Estas diferencias entre las cotizaciones de las monedas y lo que podríamos considerar «valor intrínseco» o «fundamentos», se achacan, con generalidad, a los efectos distorsionadores de los mercados financieros. Esto es así porque el objetivo de los gestores de inversión no es operar tomando en consideración las diferencias entre los valores intrínsecos (cualquiera que sea el método empleado en su estimación) y los de mercado, apostando por su convergencia a largo plazo, sino que la base de su actuación es considerar las reacciones de los otros participantes.

Este planteamiento es el empleado por Keynes, y no puede sorprender que el párrafo que sigue sea reproducido frecuentemente por los estudiosos de los comportamientos de los mercados en la actualidad:

«La gestión profesional de las inversiones puede compararse a esos concursos de los periódicos en los que los participantes tienen que seleccionar las seis caras más bellas de entre un centenar de fotografías, ganando el premio aquel competidor cuya selección se aproxime más al promedio de las preferencias de los competidores en conjunto; así pues, cada concursante ha de elegir, no las caras que él considere más bellas, sino las que crea que serán más del agrado de los demás participantes, todos los cuales analizan el problema con un planteamiento similar. No es el caso de elegir aquellas que, según nuestro propio juicio, son realmente las más bellas, ni siquiera las que la opinión general cree que efectivamente lo son. Hemos alcanzado el tercer grado en el que dedicamos nuestra inteligencia a anticipar lo que la opinión 
promedio espera que sea la opinión promedio. Y hay, según creo, quienes practican el cuarto, el quinto y grados aún superiores.»

(1936, VII, p. 156).

En dos trabajos importantes (McKinnon, 1996; McKinnon y Ohno, 1997) sobre la relación entre los tipos de cambio del dólar y del yen, se plantea como hipótesis explicativa de las diferencias extraordinariamente acusadas entre las cotizaciones de las dos monedas, no la tendencia de los datos fundamentales, sino que los gestores adoptan las decisiones en respuesta a los cambios continuos de nueva información, en particular respecto a las directrices de la política monetaria y a las expectativas y convenciones generadas en los mercados.

En cuanto a los mercados bursátiles, las fuertes fluctuaciones han dominado el panorama. La baja de la bolsa de octubre de 1987 indujo a reflexionar sobre las razones y consecuencias de las crisis bursátiles, con el telón de fondo de lo ocurrido en la Gran Depresión. La investigación realizada por encargo del presidente de los Estados Unidos concluyó que, efectivamente, se había incrementado la volatilidad de los mercados de acciones, sobre todo a partir de la generalización de los derivados (Brady, II, pp. 5-6).

La crisis de 1987 en Wall Street se transmitió a todos los mercados del mundo, obligando a una intervención pública generalizada para respaldar la liquidez y la solvencia de las instituciones. El país que menos sufrió el desplome fue Japón, cuya bolsa parecía inmunizada pese a que los niveles de PER (NOTA5) triplicaban al existente en el resto de los mercados.

Lo que se estaba gestando en Japón era una gigantesca burbuja especulativa, basada en el mercado de acciones y en el inmobiliario, que dio lugar a valoraciones espectaculares sostenidas por el sistema bancario. La caída del mercado japonés, 
iniciada a finales de la década de los ochenta, supuso una fortísima corrección de las cotizaciones bursátiles y de los precios inmobiliarios, coadyuvó a una profunda crisis bancaria y afectó al crecimiento de la economía japonesa, sumiéndola en una crisis en la cual está instalada desde entonces.

En todos los casos, la cuestión fundamental de las crisis financieras es la quiebra de unas expectativas demasiado optimistas, gestadas y alimentadas por los propios mercados. Las fuertes discrepancias entre las cotizaciones del mercado, y el precio que cabría esperar de los fundamentos que legitiman el precio de un activo y le dotan de estabilidad a largo plazo, recuerdan las reflexiones de Keynes. Es oportuna la revisión de la obra del gran economista. La Teoría General es un libro inspirado, conviene no olvidarlo, en la Gran Depresión que tuvo como pórtico el desplome de Wall Street. En esta obra, Keynes distingue entre la actividad de adivinar el comportamiento del mercado, que denomina especulación, de aquella cuyo objetivo es evaluar la rentabilidad de un activo durante su vida útil, actividad a la que reserva el término de empresa.

Una vez establecido que ciertas clases de inversiones se rigen por la evolución de la bolsa, Keynes da el paso siguiente: las expectativas respecto a la rentabilidad de los que trafican en bolsa son distintas de las del empresario profesional, y lo son porque sus patrones de valoración, y el período que abarca su interés, son diferentes. Según Keynes, los comportamientos especulativos se imponen sobre las valoraciones de los empresarios.

La idea clave de Keynes para explicar el comportamiento de los inversores en el mercado de valores es la convención que se basa en el supuesto de que «la situación existente en los negocios continuará indefinidamente, excepto cuando tengamos razones concretas para esperar un cambio» (1936, VII, p. 152). No es una creencia con base real firme, puesto que las frustraciones experimentadas en el pasado en relación 
a las expectativas son concluyentes al respecto, ni tampoco tiene fundamento en la lógica de la probabilidad esa idea de la convención adoptada como base del comportamiento:

«En efecto, lo que estamos suponiendo es que la valoración existente en el mercado, con independencia de cómo se haya llegado a ella, es correcta únicamente en relación con nuestro conocimiento actual de los hechos que influirán sobre los rendimientos de la inversión; y que sólo cambiará en proporción a las variaciones en dicho conocimiento»

(ibídem, p.152).

La existencia de la convención dota de estabilidad y continuidad a los negocios y, en tanto ésta se mantenga en los mercados organizados, el inversor puede sentirse tranquilo con la idea de que el único riesgo que arrostra es un cambio en las noticias que puedan producirse en un futuro cercano, sobre cuya probabilidad intentará formar su propio juicio. Con este planteamiento, la inversión se considera segura en el período corto y, como el inversor entiende que, o bien la convención no se altera, o él puede anticiparse a los cambios que se produzcan en el futuro, las inversiones que son fijas para la comunidad se vuelven líquidas para el individuo. Sobre este tipo de razonamientos, continúa Keynes, se han desarrollado los principales mercados de inversión, «pero no puede sorprendernos que una convención tan arbitraria, desde un punto de vista absoluto, tenga sus puntos débiles. Su precariedad es la que crea una parte no pequeña de nuestros problemas contemporáneos de procurar un volumen de inversión suficiente» (ibídem, p. 153).

El punto que interesa destacar del planteamiento de Keynes, en cuanto a la convención, es que cuando los agentes han de adoptar decisiones en un entorno incierto están psicológicamente dispuestos a actuar imitando la acción de los otros participantes. En la dirección de considerar la reacción de los participantes en los 
mercados organizados, Keynes examina algunas características que sugiere la evolución reciente de éstos, que incrementan la precariedad y, por tanto, la volatilidad de los mismos, sin que existan razones sólidas que apoyen los cambios de las valoraciones; de ellos es fundamental la separación de la gestión y la propiedad, hecho ligado al peso creciente de las acciones en las carteras de individuos e instituciones.

La creciente difusión entre el público de acciones cotizadas acentúa los efectos de la separación entre propiedad y gestión, puesto que «ha disminuido seriamente el conocimiento real en la valoración de las inversiones de los propietarios o de los que proyectan comprarlas». En este entorno de mayor ignorancia, acontecimientos efímeros y fútiles pueden provocar cambios sustanciales en la valoración de los títulos; además, la base convencional de valoración establecida como «resultado de la psicología de la masa de un gran número de individuos ignorantes es susceptible de cambios violentos como resultado de un cambio súbito de opinión, debido a factores que no afectan gran cosa al rendimiento probable»; esto significa que el mercado está sujeto a olas de optimismo y pesimismo que «no son razonables, pero, en cierto sentido, son legítimas cuando no existen bases sólidas para un cálculo razonable» (ibídem, pp. 153-154).

El inversor profesional no suple las carencias cognoscitivas de los accionistas ignorantes, porque no se dedica a eso. Al experto no le interesa tanto extremar el rigor en el cálculo de los rendimientos futuros en el largo plazo, como adivinar los cambios en las bases convencionales de valoración del público en el corto plazo:

«No se ocupan de lo que realmente vale una inversión para mantenerla, sino de la valoración que le dará el mercado bajo la influencia de la psicología de la masa, dentro de tres meses o un año. Además, esta conducta no es el resultado de una inclinación errónea. Es la inevitable consecuencia de un mercado organizado de 
acuerdo con las normas descritas; porque no es sensato pagar 25 por una inversión cuyo rendimiento probable justificaría un valor de 30, si también creemos que el mercado lo valorará en 20 dentro de tres meses»

(ibídem, p. 155).

De esta manera, el inversor profesional concentra sus esfuerzos en el análisis de las noticias que la experiencia sugiere que tienen efecto en el comportamiento de las inversiones, y éste es el resultado de los mercados que se organizan para lograr lo que se denomina como «liquidez».

«Entre las máximas de las finanzas ortodoxas, ninguna, seguramente, es más antisocial que el fetiche de la liquidez, la doctrina según la cual es una virtud positiva de las instituciones de inversión concentrar sus recursos en la tenencia de valores líquidos. Olvida que la liquidez de la inversión no existe para la sociedad en conjunto»

(ibídem, p. 155).

Keynes denuncia que en los mercados organizados los profesionales y las instituciones inversoras no se consagran para derrotar a los enemigos seculares de la sociedad, esto es, la ignorancia y la incertidumbre, sino que su objetivo principal es ser más listo y rápido que los demás y «pasar la moneda falsa, o que se está depreciando, a otra persona».

Naturalmente, también existen inversores a largo plazo que analizan la rentabilidad de las inversiones y no se preocupan de las fluctuaciones a corto plazo ni de las reacciones de los otros participantes, y la existencia de inversores de este corte dan otra fisonomía a los mercados, pero hacer estimaciones rigurosas sobre el futuro es mucho más difícil y lento: 
«Se necesita más inteligencia para derrotar las fuerzas del tiempo y nuestra ignorancia respecto al futuro que para ganar la delantera. Además, la vida no es lo bastante larga, hay un deleite particular en ganar dinero pronto, y los beneficios futuros se descuentan por el hombre medio a tasas muy altas»

(ibídem, p. 157).

El peso de la especulación en el mercado es decisivo respecto al grado de inestabilidad del mismo. Esta consideración de la especulación como factor perturbador si llegaba a constituirse en el principal elemento del mercado, rompía con la consideración tradicional de la actividad especulativa, como oportunamente analizó Kaldor (1939) en un importante artículo que profundizaba en las cuestiones apuntadas por Keynes en el capítulo 12 de la Teoría General. La idea tradicional contemplaba la especulación como positiva, ya que incorporaban sus practicantes un nivel superior de previsión, y de no ser así, serían eliminados. Ese mayor conocimiento garantizaba una actuación tendente a la mejor asignación de los recursos. Kaldor (1939, p. 102) distingue los efectos de la especulación en función de su peso en el mercado; cuando ésta es dominante, subsisten efectivamente los que realicen las mejores previsiones, pero lo fundamental ya es prever la conducta de otros especuladores antes que otros factores reales de naturaleza más permanente, y aunque los especuladores menos dotados desaparezcan, la renovación de la población dedicada a esta actividad proporciona la continuidad del predominio de la actividad basada en el comportamiento del colectivo especulador.

La diferencia entre empresarios y especuladores reside no sólo en el foco de interés, las perspectivas de la empresa y de los mercados, sino que también difieren los conocimientos de ambos colectivos, y los especuladores, con un horizonte de corto plazo, requieren para la acción una preparación distinta que los empresarios. Por estos motivos, si los especuladores consiguen imponer sus pautas de comportamiento y de valoración en la vida económica, si llegan a ser el elemento 
dominante, su actuación distorsiona la vida empresarial. En la concepción de Keynes, como ha destacado O'Donnell (1989, p. 258), ambos, especuladores y empresarios, han de afrontar un futuro desconocido, pero los empresarios tienen unas guías que pueden orientar correctamente los objetivos a largo plazo, si pudieran adoptar sus decisiones sin la interferencia de los criterios a corto plazo de los especuladores. Como Keynes precisaría en 1938, en el último discurso que dirige a los mutualistas de la National Mutual, (NOTA6) los mercados especulativos:

«Están regidos por la duda más que por la convicción, por el miedo más que por la previsión, por la memoria del pasado inmediato y no por el conocimiento del porvenir. El nivel de precios de la bolsa no refleja lo que el inversor conoce, sino lo que no conoce. Enfrentados con las perplejidades e incertidumbres del mundo moderno, la valoración de los mercados fluctuará mucho más ampliamente que lo razonable a la luz de la incidencia posterior de los sucesos»

(1938, XII, p. 238).

\section{Notas}

1.- La defensa de esta interpretación la realiza Meltzer en los siguientes trabajos: (1981): «Keynes general theory: A different perspective», Journal of Economic Literature, vol. 19, marzo, pp. 34-64; (1983): «Interpreting Keynes», Journal of Economic Literature, vol. XXI, marzo, pp. 66-78; (1983): «On Keynes and monetarism», en D. Worswick y J. Trevithick (eds.): Keynes and the modern world. Proceedings of the Keynes centenary conference, Cambridge University Press; (1989): «Keynes on monetary reform and international order», en F. Capie y G. E. Wood (eds.): Monetary Economics in the 1980s, Hong-Kong, Macmillan Press; (1992): «Patinkin on Keynes and Meltzer», Journal of Monetary Economics, 29, pp. 151-162; (1996): «The general theory after sixty years», Journal of Post Keynesian Economics, 
Fall, vol. 19, núm. 1, pp. 35-45. En Torrero (1998, pp. 1027-1035), se revisa con detalle la interpretación de Meltzer.

2.- Ontiveros (1997) expone con claridad y concisión la evolución del Fondo Monetario Internacional.

3.- Para más referencias sobre la obra de Minsky puede consultarse Torrero (1993).

4.- En Torrero (1998) se abordan estas cuestiones.

5.- Price earning ratio. Relación entre la cotización de una acción y su beneficio por acción.

6.- Keynes entró en el Consejo de Administración de la National Mutual Life Assurance Society en septiembre de 1919. Fue nombrado presidente en mayo de 1921 y permaneció en el cargo hasta octubre de 1938.

\section{Bibliografía}

BRADY, N. F. (Presidente) (1988): «Report of the presidential task force on market mechanisms», Washington, U.S. Government Printing Office.

McKINNON, R. I. (1996): «Dollar and yen», en M. Uzan (ed.), The Financial System under Stress. An Architecture for the New World Economy, Routledge, Nueva York.

McKINNON, R. I., y Ohno, K. (1997): Dollar and yen. Resolving the economic conflict between the United States and Japan, The MIT Press. 
KALDOR, N. (1939): «Speculation and economic stability», The Review of Economic Studies. Incluido en F. Targetti y A. P. Thirlwall (eds.), The Essential Kaldor, Nueva York, 1989, Holmes \& Meier, de donde se toman las referencias.

KEYNES, J. M.: Todas las referencias a las obras de Keynes corresponden a los Collected Writings, editados por The Royal Economic Society. En la bibliografía se reseña el año de publicación de la obra de Keynes, el título del libro o del artículo, así como el volumen y páginas correspondientes. En las citas, el año de publicación, el volumen y la página.

KEYNES, J. M. (1930):«The great slump of 1930», Essays in persuasion, vol. IX.

KEYNES, J. M. (1938): «Speech to the annual meeting of the national mutual, 20 febrero» (XII, pp. 231-239).

KEYNES, J. M. (1939): The general theory of employment, interest and money, vol. VII.

O’DONNELL, R. M. (1989): Keynes: Philosophy, Economics \& Politics, Londres, The MacMillan Press, Ltd.

ONTIVEROS, E. (1997): Sin orden ni concierto. Medio siglo de relaciones monetarias internacionales, Murcia.

ROGOFF, K. (1996): «The purchasing power parity puzzle», Journal of Economic Literature, vol. XXXIV, junio, pp. 647-668.

THUROW, L. (1996): The future of capitalism. How today's economic forces will shape tomorrow's world, Londres: Nicholas Brealey Publishing. 
TORRERO, A. (1993): La crisis del sistema bancario: Lecciones de la experiencia de Estados Unidos, Editorial Civitas, Madrid.

TORRERO, A. (1998): La obra de John Maynard Keynes y su visión del mundo financiero, Editorial Civitas, Madrid. 